\title{
OPTIMIZING AMOUNT OF APPLIED WATER FOR DRIP IRRIGATION SYSTEM IN NORTH NILE DELTA
}

\author{
E.M. Khalifa ${ }^{1}$, M. K. El-Nemr ${ }^{2}$, M. E. Meleha ${ }^{3}$, and M. M. Sharaf ${ }^{4}$
}

\section{ABSTRACT}

Accurate calculation of irrigation water requirement, affects directly the crop production, water use efficiency (WUE), and energy use efficiency (EUE). Two methods for calculating irrigation water requirement were compared under two types of emitters ( $R$ and $T)$. The first method was based on the Moisture Allowed Depletion (MAD) while the second based on meteorological data (Met). Three percentages of MAD, 50, 60, and $70 \%$ of available water were experimented. Experiment has taken place under clay soil in the north of Nile Delta (Sakha region). Results showed that the treatments based on the meteorological data have consumed less amounts of water. In addition, Met treatments recorded the greatest values of water application efficiency (WAE). WAE has been significantly affected by the method of water requirements calculation while type of emitter did not significantly affect the WAE. The meteorological based method gave the greatest values of crop production, WUE, and energy use efficiency (EUE) for both emitters. There was a decrease in the production for the $70 \%$ MAD as a result for water stress. This production decrease caused a decrease in WUE and EUE. It was recommended to use the meteorological based method for optimized amount of applied water that will keep the crop production and increase WUE, EUE, and WAE.

\section{INTRODUCTION}

7 he sustainability of agricultural production depends on conservation, appropriate use and management of scarce water resources especially in arid and semi-arid areas where irrigation is required for the production of food and cash crops (Douh and Boujelben, 2011).

1. Professor and head of the department of Agricultural Engineering, faculty of Agriculture, Kafrelsheikh University.

2. Assistant professor, Department of Agricultural Engineering, Faculty of Agriculture, Damietta University.

3. Professor of Researcher, Water Management Research Institute, National Water Research Center, Cairo.

4. Ph.D holder. 
Irrigation process in North Delta mainly depends on surface irrigation systems which acts $88.5 \%$ of irrigation techniques in Egypt (FAO, 2009). Production of the soil in Nile Delta faces the scarcity of both crop production and water resources. Many studies recommended replacing Surface irrigation system with modern irrigation systems or improved surface irrigation (Lijovski and Cukaliev, 2002; Omran, 2004; Song et al., 2007; and Baghani et al., 2008). These recommendations indicated that modern drip irrigation systems will help to improve different irrigation efficiencies and water use. On the average, drip irrigation saves about 70 to $80 \%$ water when compared to conventional flooding or furrow irrigation methods (Ishfaq, 2002). Most of Nile Delta soil is clay (old) soil (Abdelkawy and Ali, 2011). (Sonbol et al, 2010) Studied the effect of different irrigation systems included surface and sub-surface drip irrigation, traditional surface irrigation and gated pipes on sugar beet crop cultivated in clay soil. They found that traditional surface irrigation consumed the greatest amount of water compared to gated pipes and drip irrigation types. Drip irrigation was studied in clay soil under different crops (El-Nemr, 2002; Sonbol et al., 2009; El-Sirafy et al., 2011; and 2011). These studies focused on the performance evaluation of different irrigation systems and management scenarios, but none of them studied the effect of water requirements calculation methods despite the expected variation in the calculated amounts of water requirement. Amount of applied water is directly related to soil moisture distribution and irrigation time which result a direct effect on water use efficiency (WUE), water application efficiency (WAE), energy consumption, and energy use efficiency (EUE). These parameters are essential to be considered for irrigation systems' evaluating. The importance of the last two parameters has increased with the modernization of irrigation systems that made irrigation process the major energy consumer in agriculture (Abadia et al., 2008). Irrigation time is mainly related to the required amount of water to be applied. There are many methods to calculate water requirement. This study will focus on two methods to calculate the water requirement 1Based on different values of maximum allowed depletion of soil moisture content (MAD) 2- Meteorological data based calculations (Met). Water balance method expresses the required amount of water applied by the 
irrigation system to compensate the water loss. The objectives of this study is comparing the effect of using two different methods of water requirement calculation to recommend one of them depending on the water saving, crop production, WAE, WUE, and EUE.

\section{MATERIALS AND METHODS}

\section{Preparation of experimental area:}

The field experiment has taken place in the research farm, Faculty of Agriculture, Kafrelsheikh University, Egypt (Longitude 30.95N- Latitude 31.11E- Altitude $20 \mathrm{~m}$ ). Sweet potato (Abees) was planted during the summer season 2011/2012. The tubers were planted manually on $25^{\text {th }}$ of April 2012 after bean crop in a clay soil (Table 1). Plant spacing was $25 \mathrm{~cm}$ along rows with $70 \mathrm{~cm}$ spacing. Chisel plough (7shares) was hitched to $60 \mathrm{hp}$ tractor. During ploughing $630 \mathrm{~kg} / \mathrm{ha}$ of $\left(\mathrm{H}_{2} \mathrm{Po}_{4}\right)_{2}$ were added to the soil. $\left(\mathrm{NH}_{4}\right)_{2} \mathrm{So}_{4}, \mathrm{k}_{2} \mathrm{SO}_{4}$, and $\mathrm{k}_{2} \mathrm{O}$ were used to supply the soil with 126 Unit of Nitrogen and 384 Unit of Potassium per hectare. Nitrogen fertilizer was applied with two equal doses, 3 and 5 weeks after transplanting. Potassium fertilizer was added with two doses, 1 month and two months after transplanting.

Table 1: Some physical properties of the experiment soil.

\begin{tabular}{|c|c|c|c|c|c|c|c|c|}
\hline \multirow{2}{*}{ Depth } & \multicolumn{3}{|c|}{ Particle size distribution, } & \multirow{2}{*}{ Texture } & $\begin{array}{c}\text { Bulk } \\
\text { density, } \\
\text { kg/m }\end{array}$ & $\begin{array}{c}\text { Field } \\
\text { capacity } \\
\text { (FC), \% }\end{array}$ & $\begin{array}{c}\text { Wilting } \\
\text { point } \\
\text { (WP), } \\
\text { \% }\end{array}$ & $\begin{array}{c}\text { Available } \\
\text { water } \\
\text { (AW), \% }\end{array}$ \\
\hline $0-15$ & 21.54 & 26.64 & 51.82 & Clay & 1280 & 45.91 & 19.69 & 26.22 \\
\hline $15-30$ & 21.55 & 26.91 & 51.54 & Clay & 1298 & 41.26 & 21.29 & 19.97 \\
\hline $30-45$ & 20.53 & 25.76 & 53.71 & Clay & 1350 & 37.78 & 23.88 & 13.90 \\
\hline $45-60$ & 20.40 & 25.98 & 53.62 & Clay & 1420 & 37.48 & 24.01 & 13.47 \\
\hline Mean & 21.01 & 26.32 & 52.67 & & 1337 & 40.61 & 22.21 & 18.39 \\
\hline
\end{tabular}

2.Variables:

\subsection{Types of emitters.}

Two types of on-line emitters $\mathrm{R}$ and $\mathrm{T}$ were used to apply water. Manufacturing specifications of the two emitters are listed in Table 2.

Table 2: Emitters' manufacturing specifications.

\begin{tabular}{|ccccc|}
\hline $\begin{array}{c}\text { Emitter } \\
\text { type }\end{array}$ & $\begin{array}{c}\text { Average } \\
\text { flow rate at } \\
\mathbf{1 0 m} \text { head, } \\
\mathbf{1 / h}\end{array}$ & $\begin{array}{c}\text { Emitter } \\
\text { exponent }\end{array}$ & classification & $\begin{array}{c}\text { Manufacturing } \\
\text { Country }\end{array}$ \\
\hline $\mathrm{T}$ & 4.14 & 0.59 & Short path & Egypt \\
\hline $\mathrm{R}$ & 5.48 & 0.70 & Turbulent flow & Jordan \\
\hline
\end{tabular}




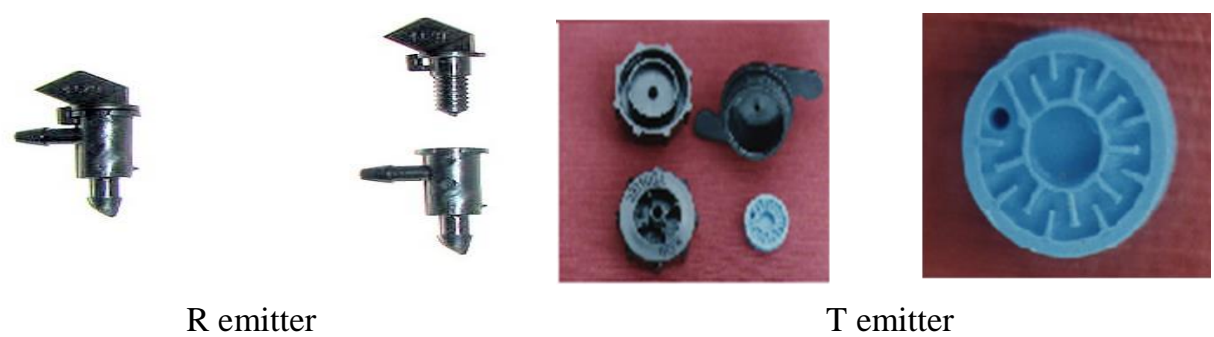

Fig. 1: Emitters' design and internal components.

Distribution uniformity (DU) indicator was used to express how the emitters can distribute water uniformly to the crop or soil (Burt et al., 1997). Distribution not only can deprive portions of the crop of needed water, but, furthermore, can over-irrigate portions of a field, leading to water-logging, plant injury, salinization, and transport of chemicals to the ground water (Solomon 1983). In order to measure DU, laterals were imaginary divided into 4 quarters. At $10 \mathrm{~m}$ operation head, samples of 7 emitters from each quarter were chosen to measure the flow rate of the chosen emitters. Graded cup $1 \mathrm{ml}$ accuracy was put under each emitter sample all at once for 2 minutes to calculate the emitters' flow rate.. DU was calculated using the following equation (Marriam and Keller, 1978):-

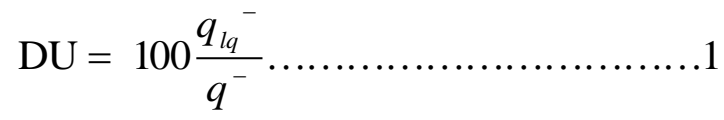

Where: $\mathrm{q}^{-}=$average of emitters flow rates, $1 / \mathrm{h}$, and $\mathrm{q}^{-} \mathrm{lq}=$ mean of lowest one-fourth of emitter flow rates, $1 / \mathrm{h}$.

\subsection{Water requirement calculation procedures.}

Amount of applied water in the field work was based on two methods of water requirement calculation. The first method is based on the soil moisture allowed depletion (MAD) as a percentage of available water. (FAO, 1998) recommended 65\% as the fraction of MAD for sweet potato. In this study, three percentages of (MAD) 50, 60, and 70\% of available water were studied. Second method is based on the meteorological data (Met) which will result the reference evapotranspiration $\left(\mathrm{ET}_{\mathrm{o}}\right)$. In order to monitor soil moisture content to decide the start time of irrigation process and amount of applied water, average of soil moisture content for the root zone at depths $15,30,45,60 \mathrm{~cm}$ from soil surface was measured using gravitational method after 24 hours from the start of irrigation process. 
Measurement of soil moisture content was replicated every 4 hours after the first 24 hours. In case of reaching the decided MAD, the irrigation process starts till reaching the FC moisture content. Met method data were cited from CLIMWAT computer program (FAO, 1993) for Sakha meteorological station which covers the experimental area. CLIMWAT program provides users with the average of daily reference evapotranspiration $\mathrm{ET}_{\mathrm{o}}$ values $\left(\mathrm{ET}_{\mathrm{o}}, \mathrm{mm} /\right.$ day) during each month of the experiment season. Amount of applied water calculation was done according to the methodology of (Sepaskhah and Ghahraman, 2004).

$$
E T_{c}=\mathrm{ET}_{o} \cdot K_{c} \cdot K_{r} \ldots \ldots \ldots \ldots \ldots \ldots . .2
$$

Where: $K c=$ crop factor which took the values $0.5,1.15$, and 0.65 , for the initial, $\mathrm{mid}$, and late growing periods of crop, (FAO, 1998). $\mathrm{K}_{\mathrm{r}}$ was calculated during the season from the ground cover (GC) value (Keller and karmeli, 1974)

$$
K_{r}=\frac{G C}{0.85} \ldots \ldots \ldots \ldots . . . . .3
$$

Irrigation frequency IF for the meteorological based method was calculated using equation 4 .

$$
I F=\frac{0.01(F C-W P)}{E T_{o}} \cdot D \cdot M A D \ldots \ldots \ldots .4
$$

Where $\mathrm{D}=$ root depth, $\mathrm{mm}$. The MAD in this case was $65 \%$ of available water referring to (FAO, 1998). Irrigation frequency has changed according to the change in monthly $\mathrm{ET}_{\mathrm{o}}$ values.

\section{Statistical design:}

Split Plot design was used in the experimental work. Emitter type (E) was the main plot while the water requirement calculation method was the sub-plot. Irristat 5.0 software was used to obtain the analysis of variance. Mstat 2.0 software was used to perform Duncan's mean comparison test.

\section{Irrigation network layout:}

The network was a part of the drip irrigation network of the research farm of Faculty of Agriculture, Kafrelsheikh University. The pump, chemigation, and filtration components (Media filter and 250 mesh screen filter) were exist to serve the whole farm. In the case of need to operate the experiment network the operator made a check for the availability of required pressure which was $10 \mathrm{~m}$. The calculations of power and energy 
were based on the design of the experimental network. The available pump was a centrifugal electric pump, $20 \mathrm{hp}(14.9 \mathrm{~kW})$. Main line, Submain line, and manifolds were P.V.C pipes with 63,30 , and $25 \mathrm{~mm}$ inside diameter. Laterals were $30 \mathrm{~m}$ length with $16 \mathrm{~mm}$ inside diameter. A schematic diagram for the experimental network is as shown in Figure. 2.

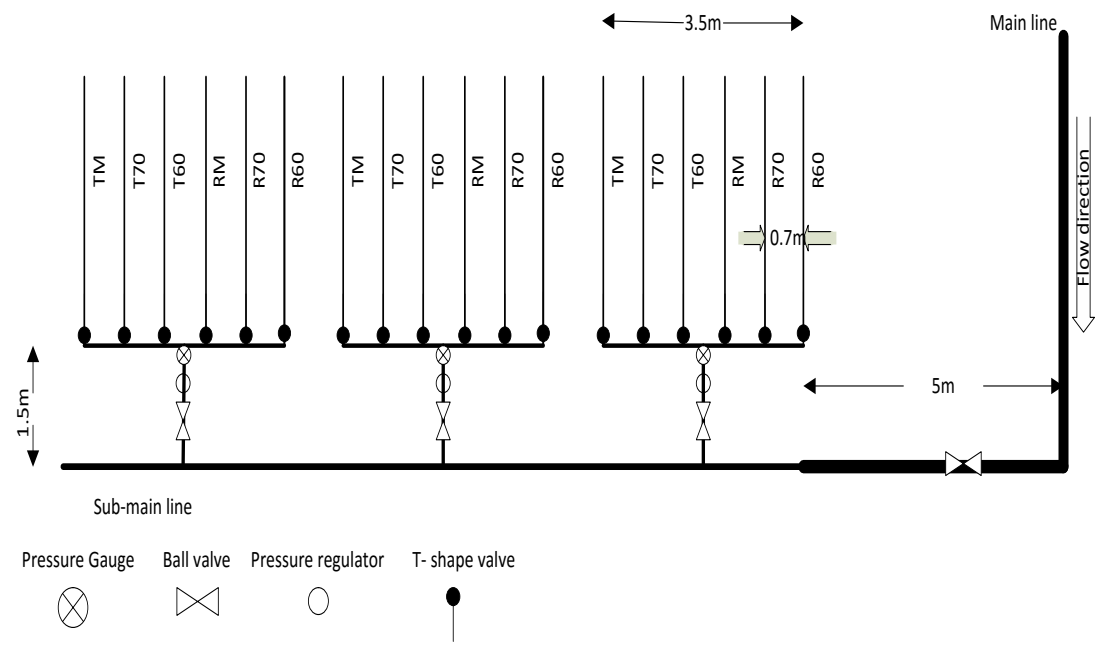

Fig. 2: A scheme for the lay out of the experiment irrigation network.

\section{Water application efficiency (WAE):}

Application efficiency relates to the actual storage of water in the root zone to meet the crop water needs in relation to the water applied to the field. It might be defined for individual irrigation or parts of irrigations (irrigation sets). Irrigation efficiency can be defined as shown in equation 5, (James, 1988).

$$
E_{a}=\frac{V_{b u}}{V_{a}} \times 100=\frac{R A W . A}{V_{a}} \times 100 \ldots \ldots \ldots \ldots \ldots . .5
$$

Where: $-\mathrm{V}_{\mathrm{bu}}=$ volume of water beneficially used by a crop in an area. $\left(\mathrm{m}^{3}\right), \mathrm{V}_{\mathrm{a}}=$ volume of water applied in the area $\left(\mathrm{m}^{3}\right), \mathrm{A}=$ irrigated area, $\mathrm{m}^{2}$, and $\mathrm{RAW}=$ readily available water, $\mathrm{m}$ which was calculated referring to (FAO, 1998).

$$
\text { RAW }=\text { MAD.TAW }
$$
6

Where: TAW is the total available water which is the difference between soil field capacity (FC) and wilting point (WP). The mean value of FC 
and WP shown in Table 1 was used in calculations. The measuring of Ea was replicated three times during the experiment season.

\section{Crop production}

Manual harvesting started after 120 days from the transplanting date. Tuberous roots for each treatment were weighed on 3 digits accuracy scale. The mean of three replicates was used to express each treatment production.

\section{Water use efficiency (WUE):}

WUE has been used to describe the relationship between sweet potato crop production and the total amount of water used. It was determined in $\mathrm{kg} \mathrm{m}^{-3}$ by applying the following equation (Jensen, 1983):

$$
\text { WUE }=\frac{Y}{W_{a}} \ldots \ldots \ldots \ldots \ldots . . .7
$$

Where: $Y=$ total yield, $\mathrm{kg} / \mathrm{ha}$, and $\mathrm{W}_{\mathrm{a}}=$ total applied water, $\mathrm{m}^{3} / \mathrm{ha}$.

\section{Energy use efficiency (EUE):}

In order to calculate the energy consumption of the irrigation network under the experimental conditions. The water pumping power requirement has to be calculated. The pump brake power was calculated as follows-:

$$
B P_{E}=\frac{P_{w}}{\eta} \ldots \ldots \ldots . . .8
$$

Where: $\mathrm{BP}_{\mathrm{E}}=$ engine brake power in $\mathrm{hp}, \mathrm{P}_{\mathrm{w}}=$ water power, $\mathrm{hp}$ and $\mathrm{\eta}=$ decimal pump efficiency which was assumed 0.7.

$$
P_{w}=\frac{\mathbf{Q} \cdot H_{t} \cdot \omega}{75} \ldots \ldots \ldots . .9
$$

Where:

$\mathrm{Q}=$ required discharge at the network $\mathrm{m}^{3} / \mathrm{s}, \mathrm{H}_{\mathrm{t}}=$ total head $\mathrm{m}$, and $\omega=$ water specific weight $\mathrm{kg} / \mathrm{m}^{3}$.

$$
H_{t}=H_{\mathrm{f}}+H_{s}+H_{e} \ldots \ldots \ldots . .10
$$

$\mathrm{H}_{\mathrm{f}}=$ friction loss in $\mathrm{m} / 100 \mathrm{~m}, \mathrm{H}_{\mathrm{s}}=$ static head, and $\mathrm{H}_{\mathrm{e}}=$ emitter operating pressure head in $\mathrm{m}$. The suction static head was $125 \mathrm{~m}$. Hazen- Williams formula (Hazen and Williams, 1920) was used to calculate the major friction loss for which included main, sub-main, manifold, and laterals losses. The constant $\mathrm{C}$ value was 150 . 


$$
H_{f}=\frac{10.67 x Q^{1.85}}{C^{1.85} X^{4.87}} \ldots \ldots \ldots \ldots \ldots . . .11
$$

Where: $\mathrm{d}=$ inside pipe diameter in $\mathrm{m}$. The minor friction loss in connectors and valves was assumed $10 \%$ of the total friction loss (ElGindy et al., 2001).

\section{Energy consumption and Energy Use Efficiency (EUE):}

The Energy was calculated by multiplying the calculated power requirement (kW.h) in the total operation time per season for each treatment. EUE indicator was used to express the crop produced from energy unit according to the following equation:

$$
E U E=\frac{\text { Total } \text { yield } \mathrm{kg}}{\mathrm{P}_{w}} \ldots \ldots \ldots \ldots \ldots . . .12
$$

\section{RESULTS AND DISCUSSIONS}

\section{Distribution uniformity (DU):}

Distribution uniformity of $\mathrm{T}$ and $\mathrm{R}$ emitters were 89.23 and $82.89 \%$ respectively, at $10 \mathrm{~m}$ head. Emitter exponent of emitter $\mathrm{T}$ was greater than its value of emitter $\mathrm{R}$ at the network operation head. Obtained values of DU reflect the expected higher uniformity of emitter $\mathrm{T}$ than emitter $\mathrm{R}$ referring to the emitter exponent values (James, 1988).

\section{Amount of applied water.}

The results showed that $\mathrm{R}$ emitter treatments consumed higher amounts of applied water than $\mathrm{T}$ emitter treatments. Increasing the MAD from 50 to $70 \%$ led to a decrease in the amount of applied water by 20.14 , and $22.27 \%$ respectively for the $\mathrm{R}$ and $\mathrm{T}$ emitters. The R70 and $\mathrm{T} 70$ were the only MAD based treatments which consumed lower amounts of water than the meteorological based calculations method. For T emitter $4.6 \%$ of water consumed by $\mathrm{T}_{\text {Met }}$ treatment will be saved if compared to $\mathrm{T} 70$ treatment. For $\mathrm{R}$ emitter $1.69 \%$ of water consumed by $\mathrm{T}_{\text {Met }}$ treatment will be saved if compared to $\mathrm{T} 70$ treatment. The water saving in $\mathrm{T}$ emitter may be due to the higher DU it shows. The higher DU means avoiding over irrigation and better soil moisture distribution leads to delay the water loss (Solomon, 1983). 
Table. 3: Amounts of applied water for the experiment treatments over the growing season $\mathrm{m}^{3} /$ ha.

\begin{tabular}{|llll|}
\hline R50 & 5234.59 & T50 & 5218.90 \\
\hline R60 & 4709.91 & T60 & 4649.83 \\
\hline R70 & 4180.34 & T70 & 4056.81 \\
\hline R $_{\text {Met }}$ & 4252.28 & T $_{\text {Met }}$ & 4252.28 \\
\hline
\end{tabular}

\section{Water application efficiency (WAE).}

The $\mathrm{T}$ emitter showed higher values of water application efficiency than the facing treatments of $\mathrm{R}$ emitter. Data listed in Table 4 showed that for the MAD based application method for both emitters, greater amount of applied water per irrigation event resulted higher WAE values. These results agree with (Sonbol et al., 2011; Tariq and Hussain, 1998) who mentioned that surface drip irrigation consumed much water if compared to sub-surface drip irrigation but resulted higher values of WAE. High water holding capacity feature of clay soil gives the ability of keeping great amounts of water in the root zone. Values of WAE were in agreement with the expected range of drip irrigation system shown by (Howell, 2003). The amount of applied water based on Meteorological data showed the greatest values of WAE for both emitters $\mathrm{R}$ and $\mathrm{T}$ if compared to MAD based application method. This may give an indicator that the meteorological based method reduces the opportunities of water loss in the root zone. Table 5 shows the analysis of variance for WAE observation resulted from the experimental variables. Water requirements calculation method had a highly significant effect on the water application efficiency, while the emitter type and interaction between the studied variables had no significant effect on WAE. This may be clarified by the mean comparison test of crop production shown in Table 4, which pointed out there was no significant difference at 0.05 level between all treatments except R60 and R70. This was in agreement with the results shown by (William and Niemiera, 1993) who mentioned that the application efficiency was unaffected by the emitters' application rate but affected by the moisture content. Comparing the $\mathrm{T}_{\mathrm{Met}}$ treatment with the greatest WAE values for $\mathrm{T}$ and $\mathrm{R}$ emitters individually, shows that using meteorological method will increase WAE by 3.17 , and $5.35 \%$ for the two emitters respectively. 
Table. 4: Water application efficiency values and mean comparison.

\begin{tabular}{|lccc|}
\hline R50 & $88.76 \mathrm{ABC}$ & T50 & $91.74 \mathrm{ABC}$ \\
\hline R60 & $86.10 \mathrm{BC}$ & T60 & $87.27 \mathrm{ABC}$ \\
\hline R70 & $85.38 \mathrm{C}$ & T70 & $86.74 \mathrm{ABC}$ \\
\hline RMet & $93.78 \mathrm{AB}$ & TMet & $94.74 \mathrm{~A}$ \\
\hline
\end{tabular}

Note: Values followed by single letter is significantly different at 0.05 level.

L.S.D $=8.372$

Table 5: Analysis of variance (ANOVA) of variables effect on WAE.

\begin{tabular}{|ccccc|}
\hline $\begin{array}{c}\text { Source of } \\
\text { Variation }\end{array}$ & DF & Sum of Squares & Mean squares & F Ratio \\
\hline Emitter(E) & 1 & 16.67 & 16.67 & $0.71 \mathrm{~ns}$ \\
Method(M) & 3 & 724.33 & 241.44 & $10.32 * *$ \\
ExM & 3 & 33.67 & 11.22 & $0.48 \mathrm{~ns}$ \\
Residual & 16 & 374.33 & 23.40 & \\
\hline Total & 23 & 1149.00 & 49.96 & \\
\hline
\end{tabular}

\section{Crop production.}

Data listed in Table 6 show the obtained crop production for the experimental treatments. The greatest crop production was under Met based calculation treatments for both emitters. For the MAD based method of $\mathrm{T}$ emitter, treatment T60 gave the greatest production with 46.75 Mg/ha while the lowest was at T70 treatment with $24.31 \mathrm{Mg} / \mathrm{ha}$. Reduction of crop production shown at T70and R70 treatments may result due to the water stress occurrence on the plants as the maximum MAD for sweet potatoes is 0.65 (FAO, 1998). Crop production did not follow the trend of WAE. The crop production in T60 and R60 was higher than T50 and R50 despite their higher WAE. This may be due to the nature of sweet potato plants. The economic part of sweet potato is the root. It is directly affected by soil moisture stress. The higher MAD led to wider roots as the MAD was kept in acceptable ranges. This may explain the crop reduction in $70 \%$ MAD treatments for both emitters $\mathrm{R}$ and $\mathrm{T}$.

Table 6: Sweet potato crop production,

$\mathrm{Mg} / \mathrm{ha}$

\begin{tabular}{|llll|}
\hline R50 & 30.48 & T50 & 38.14 \\
\hline R60 & 41.93 & T60 & 46.75 \\
\hline R70 & 22.15 & T70 & 24.31 \\
\hline R $_{\text {Met }}$ & 43.03 & TMet & 47.88 \\
\hline
\end{tabular}




\section{Water use efficiency (WUE).}

Table 7 shows the values of WUE for different treatments. The greatest value of WUE was at $T_{\text {Met }}$ while the lowest was obtained at R70 treatment. The higher values of WUE for the meteorological based treatments under both emitters may be due to the higher production and less amounts of applied water if compared to 50 and 60\% MAD treatments. The MAD based treatments showed that, $60 \%$ percentage for both emitters gave greater values of WUE than the two other percentage for both emitters. The meteorological data based method led to increase the WUE by 10.75 and $12.05 \%$ of the maximum WUE obtained from the meteorological based treatments treatments for $\mathrm{T}$ and $\mathrm{R}$ emitters respectively, if compared to T60 and R60 treatments. This may be due to the lower difference in crop production for $t$ emitters at treatments $\mathrm{T}_{\mathrm{Met}}$ and T60 than the difference of crop production for the same treatments of $\mathrm{R}$ emitter.

Table 7: Water use efficiency $\mathrm{kg} / \mathrm{m}^{3}$ for different treatments.

\begin{tabular}{|c|c|c|c|}
\hline R50 & 5.82 & T50 & 7.31 \\
\hline R60 & 8.90 & T60 & 10.05 \\
\hline R70 & 5.30 & T70 & 5.99 \\
\hline R $_{\text {Met }}$ & 10.12 & T. & 11.26 \\
\hline
\end{tabular}

\section{Energy use efficiency (EUE).}

For irrigation networks have $\mathrm{T}$ and $\mathrm{R}$ emitters in their laterals, the power requirements per hectare were 6.4 , and $8.5 \mathrm{~kW}$ for $\mathrm{T}$ and $\mathrm{R}$ emitters respectively. Emitter $\mathrm{R}$ treatments showed less values of consumed energy than $\mathrm{T}$ emitter treatments as shown in Table 8 . This may be due to the higher flow rate of emitter $\mathrm{R}$ which caused less operation time for irrigation process. On the other hand EUE values of $\mathrm{T}$ emitter treatments were higher than $\mathrm{R}$ emitter treatments. Meteorological based method recorded the greatest values of EUE. Treatment $\mathrm{T}_{\text {Met }}$ gave the greatest value of EUE with a value of $277.08 \mathrm{~kg} / \mathrm{kW}$.h. The percentage $60 \%$ MAD showed the highest values. Referring to (Ozkan et al, 2004 and singh et al., 2002), the higher DU and WAE of T emitter caused the increase in EUE. 
Table 8: Energy consumption and EUE of different experiment treatments.

\begin{tabular}{|cccc|}
\hline & $\begin{array}{c}\text { Operation time } \\
\text { h/season }\end{array}$ & $\begin{array}{c}\text { Energy } \\
\text { consumption } \mathbf{k W . h}\end{array}$ & $\begin{array}{c}\text { Energy use } \\
\text { efficiency kg/kW.h }\end{array}$ \\
\hline R50 & 31.82 & 196.69 & 154.96 \\
\hline R60 & 31.51 & 192.36 & 217.98 \\
\hline R70 & 30.69 & 188.87 & 117.28 \\
\hline RMet & 27.00 & 164.99 & 260.81 \\
\hline T50 & 23.14 & 203.65 & 187.28 \\
\hline T60 & 22.63 & 201.66 & 231.82 \\
\hline T70 & 22.22 & 196.42 & 123.77 \\
\hline TMet & 19.41 & 172.80 & 277.08 \\
\hline
\end{tabular}

\section{CONCLUSION}

Depending on the meteorological based method for optimized calculation of water requirement under the experimental conditions, leads to water saving, higher crop production, WUE, EUE. The higher DU the emitter can achieve will increase the WAE, WUE, and EUE. Amount of applied water will significantly affect the WAE while emitter type has no significant effect. In case of meteorological data absence, MAD should not exceed $60-65 \%$ of available water for obtaining higher WUE and EUE. More studies should be done for comparing different methods of water requirement calculation including different soil and emitter types.

\section{REFERENCES}

Abadia, R.; C. Rocamora; A.Ruiz; and H. Puerto (2008). Energy efficiency in irrigation distribution net-works I: Theory. Biosystems Engineering, 101(1): 21-27.

AbdelKawy, W.A.M. ; and R.R. Ali (2011). Assessment of soil degradation and resilience at northeast Nile Delta, Egypt: The impact on soil productivity. The Egyptian Journal of Remote Sensing and Space Sciences. (2012) 15:19-30.

Allen, R.G.; L.S. Pereira; D. Raes; and M. Smith (1998). Crop evapotranspiration - Guidelines for computing crop water requirements - FAO Irrigation and drainage paper 56. 
Baghani, J.; K. B. Reza; J. Mohammad; and D. Hossein (2008). The study of yield and water use efficiency of sugar beet, Potato, tomato and green corn in drip and surface irrigation systems. Agricultural Engineering Research institute of Iran. Report Number 29034, 70P.

Burt, C.M. ; A. J. Clemmens; T.S. Strelkoff; K.H. Solomon; and R. D. Bliesner (1997). Journal of Irrigation and Drainage Engineering 123:6 (November 1, 1997), pp. 423-442.

Douh, B.; and A. Boujelben (2011). Improving water use efficiency for a sustainable productivity of agricultural systems with using subsurface drip irrigation for maize (Zea mays L.), Journal of Agricultural Science and Technology B1 (JAST), pp 881-888.

El-Gindy A.M.; A.A. Abdelaziz; and A.A. Soliman (2001). Irrigation and Drainage Networks Design, (in Arabic) Ain Shams University, Egypt.

El-Nemr, M.K. (2002). A study on drip irrigation system in Delta soil. M.Sc. thesis, Department of Agricultural mechanization, Faculty of Agriculture, Kafrelsheikh branch. Tanta University. Egypt.

El-Sirafy, Z.M.; H.A. Sonbol; E. A. Gazia; H.A. Shams El-Deen; and S. $H$. Rashed (2011). Maximizing water and $n$ fertilizer use efficiencies under wheat crop at north delta . Mansoura Journal of Soil sciences and Agricultural Engineering, vol 37(8): 799-812.

FAO (1993). CLIMWAT for CROPWAT, FAO Irrigation and Drainage Paper 49.

FAO (1998) Crop Evapotranspiration- Guidelines for Computing Crop Water Requirements, FAO Irrigation and Drainage Paper 56.

FAO (2009). FAO's Information System on Water and Agriculture (online). Available at" http://www.fao.org/nr/water/aquastat/countries_regions/egypt/index.s tm." Viewed April 4, 2014.

Hazen A.; and G.S. Williams (1920). Hydraulic Tables, 3rd ed., John Wiley and Sons, New York.

Howell, T.A. (2003). Irrigation Efficiency, in Encyclopedia of Water Science. Marcel Dekker, Inc. New York, New York. 1076 pp. 
Howell, T.A. (2008). Irrigation Efficiency, in Encyclopedia of Water Science second edition. CRC press Taylor\& Francis group New York. 640-641.

Ishfaq, M. (2002). Water New Technology, Global Water Institute, Lahore, Pakistan.

James, L.G. (1988). Principles of farm irrigation system design. John willey \& sons, inc. New York.

Jensen, M.E. (1983). Design and Operation of Farm Irrigation Systems, ASAE, Michigan, USA,p 827.

Keller, J. and Karmeli, D.(1974). Trickle irrigation design parameters. Trans of the ASAE 17(4):678-684.

Lijovski, I.; and O. Cukaliev (2002). The results of comparative research of tomato irrigated with drip and furrow irrigation. Proceedings of the international Eco-conference 2000. pp179-183 Novi sad.

Marriam, J.L.; and L. Keller (1978). Farm irrigation system evaluation: A guide for management. Utah State University, Logan, Utah. Dept. of Agricultural \& Irrigation Engineering.

Omran, W. M. E. (2004). Soil Water Movement as influenced by soil properties and irrigation. Ph. D. Fac. Of Agric. Minufiya University.

Ozkan, B.; H. Akcaoz ;C. Fert (2004). Energy input-output analysis in Turkish agriculture. Renewable Energy, 29:39-51.

Sepaskhah A.R.; and B. Ghahraman (2004). The effects of irrigation efficiency and uniformity coefficient on relative yield and profit for deficit irrigation. Biosystems Engineering 87 (4), 495-507.

Singh, H.; D. Mishra; and N.M. Nahar (2002). Energy use pattern in production agriculture of a typical village in arid zone India-Part I. Energy Conversion and Management, 43(16):2275-2286.

Solomon, K. H. (1983). "Irrigation uniformity and yield theory," $\mathrm{PhD}$ thesis, Utah State Univ., Logan, Utah.

Sonbol, H.A.; E.M. El Hadidi; M.M. Saied and H.M. Abo El-Soud (2009). Comparison of some types of surface and drip irrigation systems on maize crop. Mansoura Journal of Soil sciences and Agricultural Engineering, vol 34(6): 7199-7210. 
بالتنقيط تحت ظروف التربة الطينية. شملت الدر اسة استخدام نو عين من النقاطات R, T لإضافة

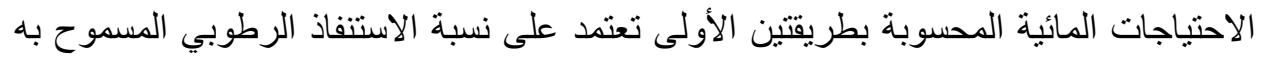

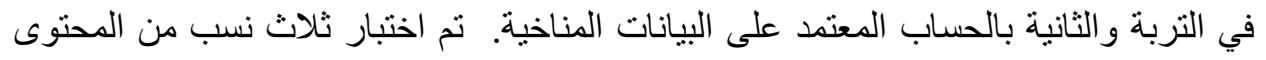

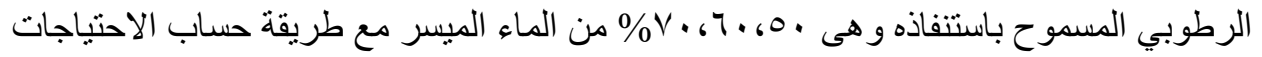

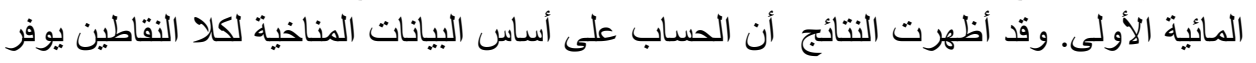

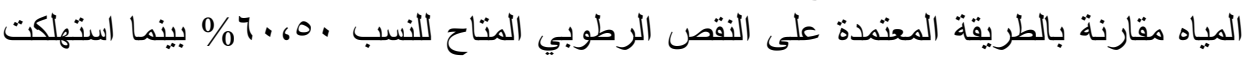

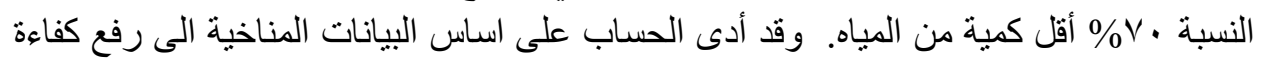

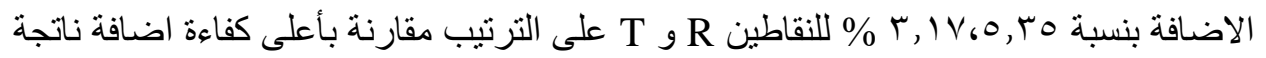

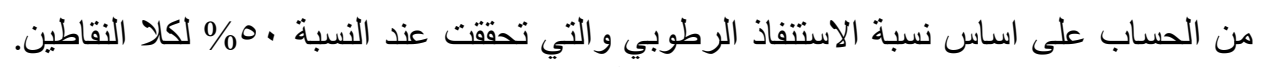

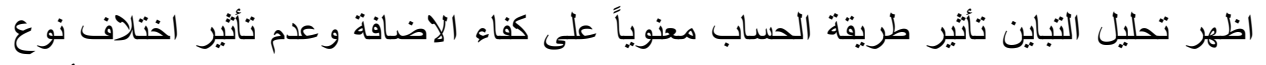

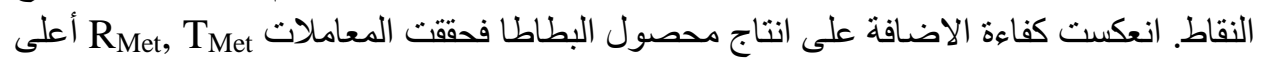

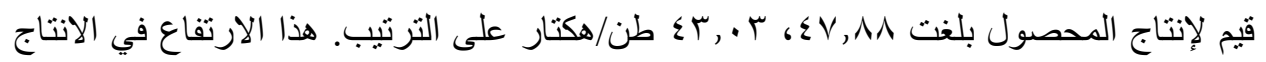
مع التوفير في كمية المياه المضافة ادى الى ارتفاع في كفاءة استخدام المياه للمعاملات المحسوبة الماته

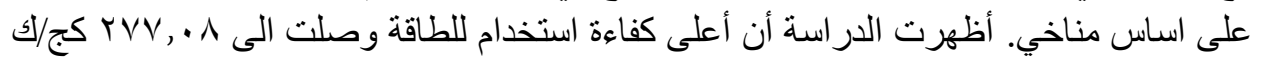
واط. س عند المعاملة Tet وبالنسبة للنقاط R سجلت المعاملة المعتمدة على البيانات المناخية

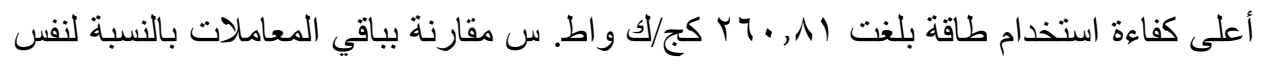

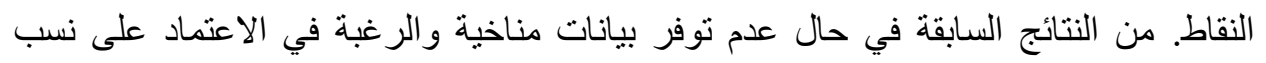

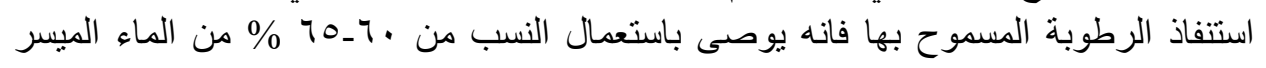

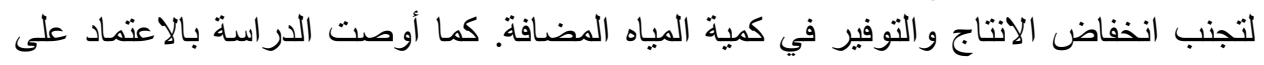
البيانات المناخية في حساب الاحتياجات المائية من أجل ضبط كمية المياه المضافة لنظاه النيام الرىى بالتنقيط في أراضي شمال الدلتا مما يؤدي الى توفير المياه وزيادة الانتاج بما يتبعه من زيادة فيطة لكفاءة الاضافة ، كفاءة استخدام المياه، كفاءة استخدام الطاقة. 